\title{
EFFECTS OF STRESS STATE WHILE DRIED ON LEATHER MECHANICAL PROPERTIES
}

\section{INFLUENTA TENSIUNII ASUPRA PROPRIETĂTILOR MECANICE ALE PIELII ÎN STARE USCATĂ}

\author{
Wei TIAN ${ }^{1}$, Jing DU ${ }^{1}$, Keyong TANG ${ }^{1 *}$, Fang WANG $^{1}$, Kang $Z \mathrm{ZHAO}^{1}$, Mădălina $A L B U^{2}$ \\ ${ }^{1}$ College of Materials Science and Engineering, Zhengzhou University, Henan 450001, P. R. China, keyongtangzzu@yahoo.com
}

${ }^{2}$ INCDTP - Division Leather and Footwear Research Institute, Collagen Department, 93 Ion Minulescu Str., 031215, Bucharest, Romania

\section{EFFECTS OF STRESS STATE WHILE DRIED ON LEATHER MECHANICAL PROPERTIES}

ABSTRACT. After being chrome tanned, the wet blue was retanned, neutralized, and fatliquored with Coripol MK to get different leather samples. Under the condition of ambient drying and vacuum drying, different forces were applied on above leather samples to provide different stress states, i.e., uniaxial stress state and biaxial stress state. The effect of different stress while dried on leather mechanical properties was investigated. Combined with the SEM results of grain and cross section, the change patterns were discussed. They indicate that after drying with stretching, the tensile strength and the stiffness of the samples are increased while the elongation at break is decreased. Compared with the sample being biaxial stress processed, the sample with a uniaxial stress process is higher in tensile strength and lower in elongation at break. After being dried and stretched, the grain smoothness of the sample becomes better. Uniaxial stretching increases the orientation degree of the collagen fiber in the sample, while biaxial stretching may separate the collagen fiber bundles. On the basis of the work, a simplified fiber structure model during stretching was proposed.

KEY WORDS: stress state; leather; mechanical property; tensile strength; elongation at break; fiber orientation

\section{INFLUENTA TENSIUNII ASUPRA PROPRIETĂTILOR MECANICE ALE PIELII ÎN STARE USCATĂ}

REZUMAT. După tăbăcirea în crom, pieile wet blue au fost retăbăcite, neutralizate şi unse cu Coripol MK pentru a obţine diferite probe de piele. În condiţii de uscare la temperatura camerei şi uscare în vid, s-au aplicat diferite forţe pe suprafaţa probelor de piele pentru a cauza diferite tensiuni, de exemplu, tensiunea uniaxială şi cea biaxială. S-a investigat influenţa diferitelor tensiuni în condiţii de uscare asupra proprietăţilor mecanice ale pielii. În combinaţie cu rezultatele SEM ale suprafeţei pielii şi secţiunii transversale, s-au discutat tiparele de schimbare. Acestea indică faptul că după uscare şi întindere, rezistenţa la rupere şi rigiditatea probelor cresc, în timp ce alungirea la rupere scade. Comparativ cu proba supusă întinderii biaxiale, proba solicitată uniaxial are o rezistenţă la rupere mai mare şi o alungire la rupere mai mică. După uscare şi întindere, netezimea feţei probei de piele se îmbunătăţeşte. Întinderea uniaxială creşte gradul de orientare al fibrei de colagen, în timp ce întinderea biaxială poate separa fasciculele de fibre de colagen. Pe baza experimentelor, s-a propus un model simplificat de structură a fibrelor în timpul întinderii.

CUVINTE CHEIE: tensiune, piele, proprietăţi mecanice, rezistenţă la rupere, alungire la rupere, orientarea fibrelor

L'INFLUENCE DE LA PRESSION SUR LES PROPRIÉTÉS MÉCANIQUES DU CUIR SEC

RÉSUMÉ. Après le tannage au chrome, les peaux bleues humides ont été retannées, neutralisées et graissées de Coripol MK pour obtenir de différents échantillons de cuir. Dans les conditions de séchage à la température ambiante et séchage sous vide, on a appliqué de différentes forces à la surface de l'échantillon de cuir pour provoquer des pressions différentes, par exemple, la pression uniaxiale et la pression biaxiale. On a étudié l'influence de diverses conditions de pression sur les propriétés mécaniques du cuir sec. Les modèles de changement ont été discutés en combinaison avec les résultats MEB de la surface et du coup transversale du cuir. Cela indique que, après séchage et étirage, la résistance à la traction et la rigidité des échantillons augmentent, tandis que l'allongement à la rupture diminue. L'échantillon soumis à la pression uniaxiale a une résistance à la traction plus élevée et un allongement à la rupture inférieur par rapport à l'échantillon soumis à la pression biaxiale. Après avoir été séché et étiré, la souplesse du grain de l'échantillon de cuir améliore. L'étirage uniaxial augmente le degré de l'orientation des fibres de collagène, tandis que l'étirage biaxial peut séparer les faisceaux de fibres de collagène. À partir des expériences, on a proposé un modèle simplifié de la structure des fibres pendant l'étirage.

MOTS CLÉS: pression, cuir, propriétés mécaniques, résistance à la traction, allongement à la rupture, orientation des fibres

\section{INTRODUCTION}

In leather making, skins and leathers usually endure different kinds of forces, which not only determines some important properties of the resultant leathers, such as tensile strength, elongation, elasticity, and softness, but also affects the use performance of leather and leather goods. It is of great importance and

\section{INTRODUCERE}

În procesul de fabricare a pielii, pielea este supusă de obicei diferitelor tipuri de forţe, care determină nu numai proprietăţi importante ale pieilor finite, cum ar fi rezistenţa la rupere, alungirea, elasticitatea şi moliciunea, dar afectează şi performanţa de utilizare a pielii şi articolelor din piele. Studiul reacţiei pielii la

Correspondence to: Keyong TANG, College of Materials Science and Engineering, Zhengzhou University, Henan 450001, P. R. China,email: keyongtangzzu@yahoo.com 
significance to study the response of leather to the different forces in theory, to know the mechanism and laws of response for further understanding the structure and properties of leathers, and for the optimization of leather making techniques [1-4].

As a kind of material, the mechanical properties of leathers are very important for application [5]. Drying is one of the key operations in leather manufacturing. The final style, elasticity and texture are formed while being dried. Different drying methods will result in finished leathers with different performances, especially mechanical properties. Tension in the drying process can greatly affect the rigidity and area yield of leathers. Biaxial stretching might affect the strength and seldom affect the fracture energy. The tensile strength increases with increasing the apparent density, while decreases with increasing the drying rate [6].

C. K. Liu and colleagues studied the tensile strength, elongation at break, tearing properties of leathers, and found that the physical properties of leathers may be evaluated with the combination of fracture energy and tensile strength or elongation at break. Elongation at break may stand for the softness, tensile strength may stand for fastness. So there is a close relation between the mechanical properties and service performance of leathers [7].

In this paper, cattle hide wet blues were retanned with glutaraldehyde and fatliquored with Coripol MK to prepare leather samples. The samples were then dried at ambient pressure or vacuum dried, under the conditions of uniaxial stretching and biaxial stretching. The mechanical properties of the samples were studied and scanning electron microscope (SEM) was used to observe the grains and cross section of the samples. Stretching while being dried increases the tensile strength, stiffness, and grain smoothness of leathers, while decreases the elongation at break. Compared with those of the biaxial stretching sample, the uniaxial stretched one behaves higher in tensile strength, and lower in elongation at break. Uniaxial stretching improves the orientation degree of collagen fibers to arrange the fibers more closely, while biaxial stretching increases the space between collagen fibers. diferitele forţe teoretice, cunoaşterea mecanismului şi a legilor de reacţie este de mare importanţă pentru o înţelegere mai aprofundată a structurii şi proprietăţilor pielii, precum şi pentru optimizarea tehnicilor de fabricare a pielii [1-4].

Proprietăţile mecanice ale pielii ca material sunt foarte importante pentru utilizarea acesteia [5]. Uscarea este una dintre operaţiunile cheie din procesul de fabricare a pielii. Aspectul, elasticitatea şi textura finale se formează în timpul uscării. Diferite metode de uscare conferă pieilor diferite performanţe şi, mai ales, proprietăţi mecanice. Tensiunea din procesul de uscare poate afecta în mare măsură rigiditatea şi suprafaţa pielii. Întinderea biaxială ar putea afecta rezistenţa şi rareori energia necesară propagării fisurii. Rezistenţa la rupere creşte odată cu creşterea densităţii aparente, scăzând odată cu creşterea vitezei de uscare [6].

C. K. Liu şi colaboratorii săi au studiat rezistenţa la rupere, alungirea la rupere şi rezistenţa la sfâşiere a pielii şi au constatat că proprietăţile fizice ale pielii pot fi evaluate prin combinaţia dintre energia necesară propagării fisurii şi rezistenţa la rupere sau alungirea la rupere. Alungirea la rupere poate reprezenta moliciunea, iar rezistenţa la rupere poate reprezenta stabilitatea. Deci există o relaţie strânsă între proprietăţile mecanice şi performanţa pielii [7].

În această lucrare, s-au retăbăcit piei bovine wet blue cu glutaraldehidă şi s-au uns cu Coripol MK pentru a pregăti probele de piele. Probele au fost apoi uscate la presiune ambiantă sau uscate sub vid, în condiţii de întindere uniaxială şi biaxială. Proprietăţile mecanice ale probelor au fost studiate şi s-a utilizat microscopul electronic (SEM) pentru a observa stratul de faţă şi secţiunea transversală a probelor. Întinderea în timpul uscării măreşte rezistenţa la rupere, rigiditatea şi netezimea suprafeţei pielii, ducând în acelaşi timp la scăderea alungirii la rupere. În comparaţie cu proba supusă întinderii biaxiale, cea solicitată uniaxial are o rezistenţă la rupere mai mare şi o alungire la rupere mai mică. Întinderea uniaxială îmbunătăţeşte gradul de orientare al fibrelor de colagen, ducând la o dispunere mai strânsă a fibrelor, în timp ce întinderea biaxială duce la mărirea spaţiului dintre fibrele de colagen. 


\section{EXPERIMENTAL}

\section{Main Materials and Equipment}

Wet blue leather was purchased from a local tannery. Five-drum tanning machine, DJD-350, was made by Wuxi Derun Light Industry Machinery factory, China. Universal electronic testing machine controlled by a microcomputer was made by Sans Metering Technology Co. Ltd., China. Analog Mechanical stretcher was designed and made by ourselves.

\section{Methods}

Preparation of the Samples

After being sampled $50 \mathrm{~cm}$ in length and $50 \mathrm{~cm}$ in width in the symmetric parts, the samples were glutaraldehyde retanned, neutralized and fatliquored. After being fatliquored, a $5 \mathrm{~cm} \times 5 \mathrm{~cm}$ square was signed to indicate the stretching directions when being dried.

\section{Simulation of Stretching}

Both uniaxial stretching, biaxial stretching (plane stress state), and cyclic uniaxial stretching were used according to reference [8].

\section{Mechanical Properties}

The mechanical properties of different leather samples were studied by using the Universal electronic testing machine. The national standard dumbbell specimens were used to $\mathrm{GB} / \mathrm{T}$ 1040.32006. The tensile speed was $100 \mathrm{~mm} / \mathrm{min}$ and the stress-strain curve was automatically given by the computer.

\section{SEM Observation}

A field emission scanning electron microscopy (SEM), JSM-7500F, made in Japan was employed to observe the morphology of the grain and cross section of the samples. In order to eliminate the charge effect under high magnification, to increase the conductivity of the specimens, gold spraying was conducted before observing by SEM.

\section{PARTEA EXPERIMENTALĂ}

\section{Principalele materiale şi echipamente}

Pielea wet blue a fost achiziţionată de la o tăbăcărie locală. S-a utilizat o instalaţie de tăbăcire cu cinci butoaie, DJD-350, fabricată de Wuxi Derun Light Industry Machinery Factory, China. Echipamentul electronic universal de testare controlat de un microcomputer a fost fabricat de Sans Metering Technology Co. Ltd., China. Dispozitivul de solicitare mecanică a fost proiectat şi realizat de autori.

\section{Metode}

\section{Pregătirea probelor}

Probele cu dimensiuni de $50 \mathrm{~cm}$ lungime şi $50 \mathrm{~cm}$ lăţime au fost retăbăcite cu glutaraldehidă, neutralizate şi unse. După ce au fost unse, s-a marcat un pătrat de 5 $\mathrm{cm} \times 5 \mathrm{~cm}$ pentru a indica direcţiile de întindere în timpul uscării.

\section{Simularea întinderii}

Solicitarea uniaxială, cea biaxială (starea plană de tensiune) şi cea ciclică uniaxială s-au efectuat conform [8].

\section{Proprietăţile mecanice}

Proprietăţile mecanice ale diferitelor probe de piele au fost studiate $\mathrm{cu}$ ajutorul echipamentului electronic universal de testare. S-au utilizat specimene standard de tip ganteră, conform GB/T 1040.3-2006. Viteza de tracţiune a fost de $100 \mathrm{~mm} / \mathrm{min}$, iar curba tensiune-deformaţie a fost redată în mod automat de către calculator.

\section{Observaţii SEM}

S-a utilizat un microscop electronic de baleiaj cu emisie de câmp (SEM), JSM-7500F, fabricat în Japonia, pentru a observa morfologia suprafeţei şi a secţiunii transversale a probelor. Pentru a elimina efectul de încărcare la magnitudine mare şi pentru a creşte conductivitatea probelor, s-a pulverizat aur înainte de observarea cu ajutorul SEM. 


\section{RESULTS AND DISCUSSION}

\section{Effect of Stretching on the Mechanical Properties}

\section{Samples Dried at Ambient Pressure}

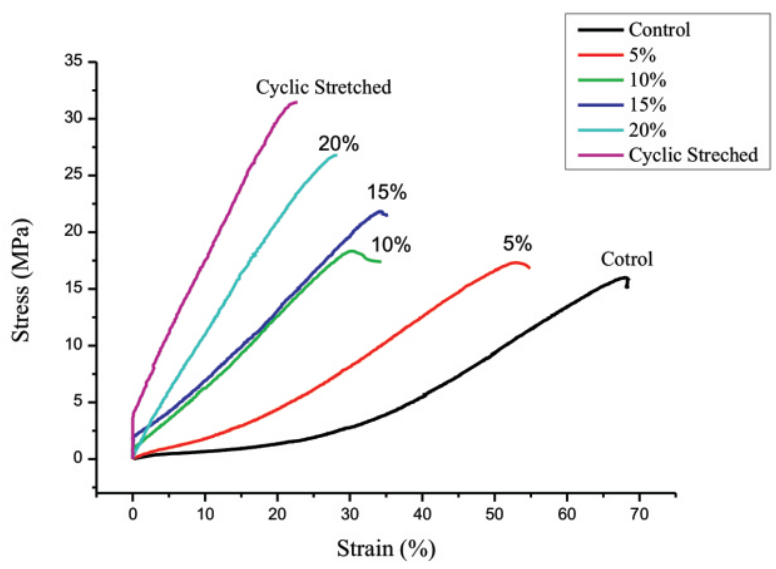

Figure 1. Stress-strain curves of samples uniaxial stretched and dried at ambient pressure

Figura 1. Curbele de tensiune-deformaţie ale probelor solicitate uniaxial uscate la presiune ambiantă

The stress strain curves of the samples uniaxial stretched while being dried at ambient pressure were shown in Figure 1. With increasing the stretching ratio of the sample while being dried, both the tensile strength and elastic modulus increase, whilst the elongation at break decreases gradually. The relations between tensile strength, elongation at break with the stretching ratio while being dried are shown in Figure 2. Drying is a process by which collagen fibers in the samples are positioned. By the combination of stretching with drying, the collagen fibers in leathers are oriented along the stretching direction to be rearranged and located. As a result, the internal structure of leathers becomes more regular and orderly, and the collagen fibers are piled up more closely. When the samples are stretched again, less space is available for collagen fibers to move, indicating an increased tensile strength and decreased elongation at break. Less difference was found between elongation at break of the samples of $10 \%$ and $15 \%$, but a great difference in the tensile strength of the cyclic stretched one. By the

\section{REZULTATE ŞI DISCUTII}

\section{Influenţa solicitării asupra proprietăţilor mecanice}

Probe uscate la presiunea ambiantă

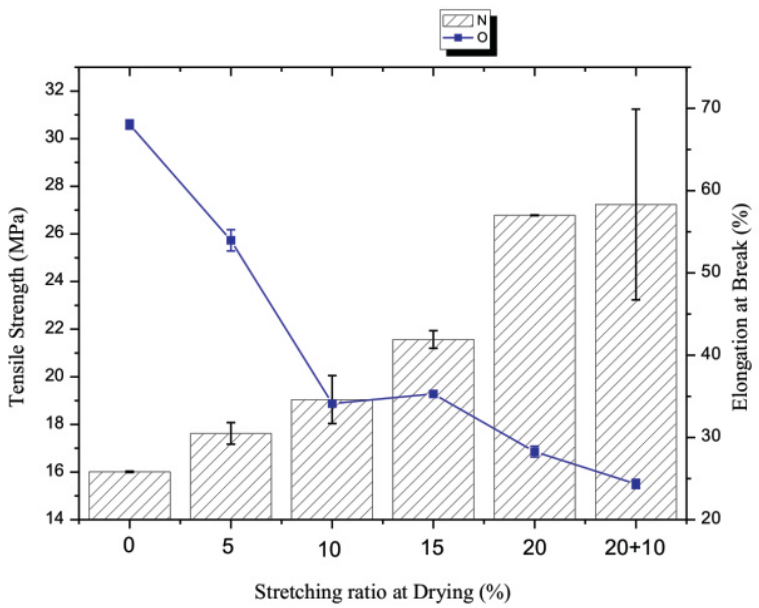

Figure 2. Tensile strength and elongation at break of samples uniaxial stretched and dried at ambient pressure vs. stretching ratio

Figura 2. Rezistenţa la rupere şi alungirea la rupere ale probelor solicitate uniaxial uscate la presiune ambiantă în funcţie de raportul de întindere

Curbele de tensiune şi deformaţie ale probelor supuse solicitării uniaxiale uscate la presiune ambiantă sunt prezentate în Figura 1. Odată cu creşterea raportului de întindere a probei în timpul uscării, atât rezistenţa la rupere, cât şi modulul de elasticitate cresc, în timp ce alungirea la rupere scade treptat. Raporturile dintre rezistenţa la rupere, elongaţia la rupere şi raportul de întindere în timpul uscării sunt prezentate în Figura 2. Uscarea este un proces în care fibrele de colagen din probe se aranjează. Prin combinarea întinderii cu uscarea, fibrele de colagen din piele sunt orientate de-a lungul direcţiei de întindere pentru a se rearanja. Ca urmare, structura internă a pieilor devine mai regulată şi mai ordonată, iar fibrele de colagen se aşează mai strâns. Când probele sunt întinse din nou, rămâne mai puţin spaţiu pentru deplasarea fibrelor de colagen, ceea ce indică o rezistenţă la rupere ridicată şi o alungire la rupere scăzută. S-a constatat o diferenţă mai mică privind alungirea la rupere a probelor, de $10 \%$ şi 15\%, şi o diferenţă mare privind rezistenţa la rupere a probei supuse la solicitare ciclică. Prin întindere ciclică 
cyclic stretching and conditioning, the collagen fibers are arranged more closely with the result of decreased stress concentration. Therefore, cyclic stretching and conditioning to certain extent yields leathers with increased tensile strength.

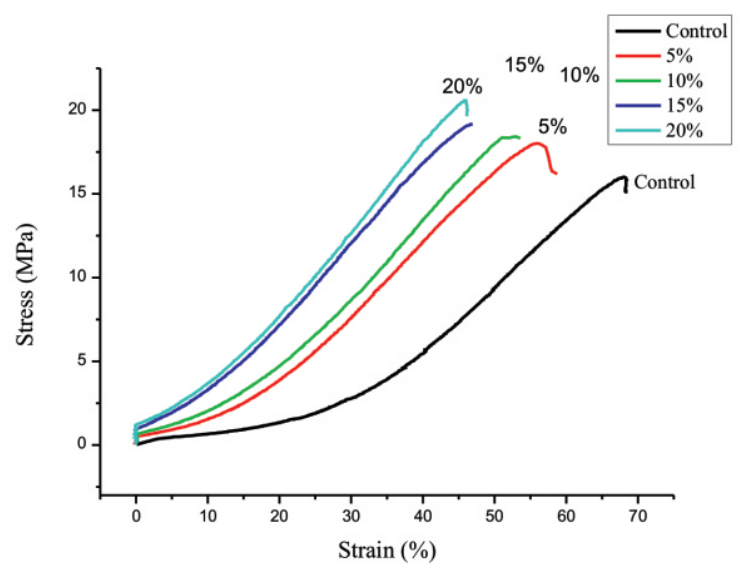

Figure 3. Stress-strain curves of samples biaxial stretched and dried at ambient pressure Figura 3. Curbele de tensiune-deformaţie ale probelor solicitate biaxial uscate la presiune ambiantă

The stress strain curves of the samples biaxial stretched while being dried are shown in Figure 3. A similar changing trend in the stress strain curves was found from Figure 3 . With the increase of stretching ratio when being dried, the tensile strength gradually increases, but the elongation at break decreases, as shown in Figure 4. Compared with the tensile strength of uniaxial stretched samples (17.6 27.1 MPa, Figure 2 ), the changes in tensile strength of the biaxial stretched samples are very few, 18.5 20.6 MPa. As to the elongation at break, the variation is great. With the increase of stretching ratio when being dried, the elongation at break decreases, but the elastic modulus increases gradually. While being biaxial stretched, the samples are in the stress state of two perpendicular directions, namely a plane stress state. As to the orientation of collagen fibers, the collagen fibers will be arranged to the stretching direction at the uniaxial stretching, while the biaxial stretching results in the arrangement of collagen fibers to two perpendicular directions. Therefore, the orienting şi condiţionare, fibrele de colagen sunt aranjate mai strâns, având ca rezultat scăderea tensiunii. Prin urmare, întinderea ciclică şi condiţionarea într-o anumită măsură conferă pieilor o rezistenţă la rupere ridicată.

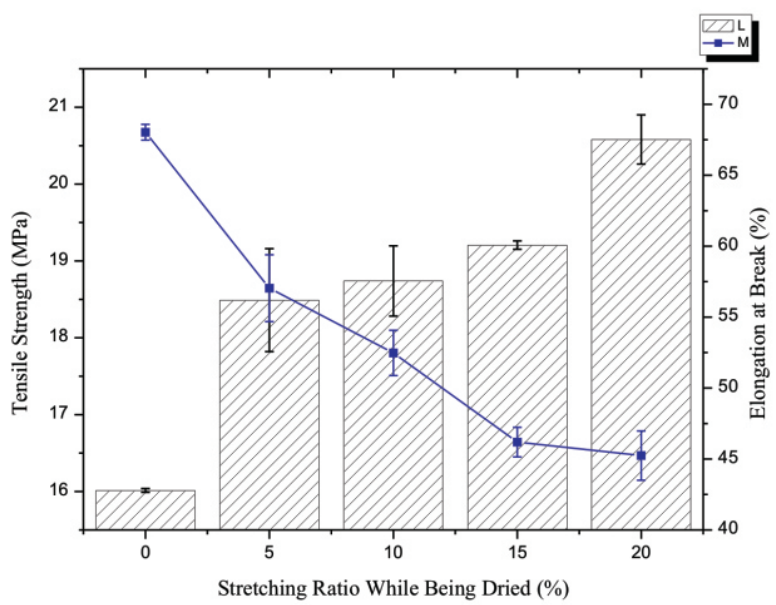

Figure 4. Tensile strength and elongation at break of samples biaxial stretched and dried at ambient pressure vs. stretching ratio

Figura 4. Rezistenţa la rupere şi alungirea la rupere ale probelor solicitate biaxial uscate la presiune ambiantă în funcţie de raportul de întindere

Curbele de tensiune şi deformaţie ale probelor supuse solicitării biaxiale în timpul uscării sunt prezentate în Figura 3. Din Figura 3 se observă o tendinţă de schimbare similară a curbelor de tensiune şi deformaţie. Odată cu creşterea raportului de întindere în timpul uscării, rezistenţa la rupere creşte treptat, dar alungirea la rupere scade, aşa cum arată Figura 4. În comparaţie cu rezistenţa la rupere a probelor solicitate uniaxial (17,6 27,1 MPa, Figura 2), modificările rezistenţei la rupere a probelor supuse solicitării biaxiale sunt foarte mici, de 18,5 20,6 MPa. În ceea ce priveşte alungirea la rupere, variaţia este mare. Odată cu creşterea raportului de întindere în timpul uscării, alungirea la rupere scade, dar modulul de elasticitate creşte treptat. La solicitarea biaxială, probele sunt în stare de tensiune între două direcţii perpendiculare, şi anume starea plană de tensiune. În ceea ce priveşte orientarea fibrelor de colagen, acestea se aranjează pe direcţia de întindere uniaxială, în timp ce întinderea biaxială are ca rezultat aranjamentul fibrelor de colagen în două direcţii perpendiculare. Prin 
degree in any direction cannot be higher than that of the uniaxial stretched one. The contribution from biaxial stretching to the tensile strength is less than that from the uniaxial one, resulting in the little change in tensile strength of biaxial stretched ones. After the samples are stretched and dried, the collagen fibers are in partial equilibrium state. Once stretched again, a small elongation at break will appear.

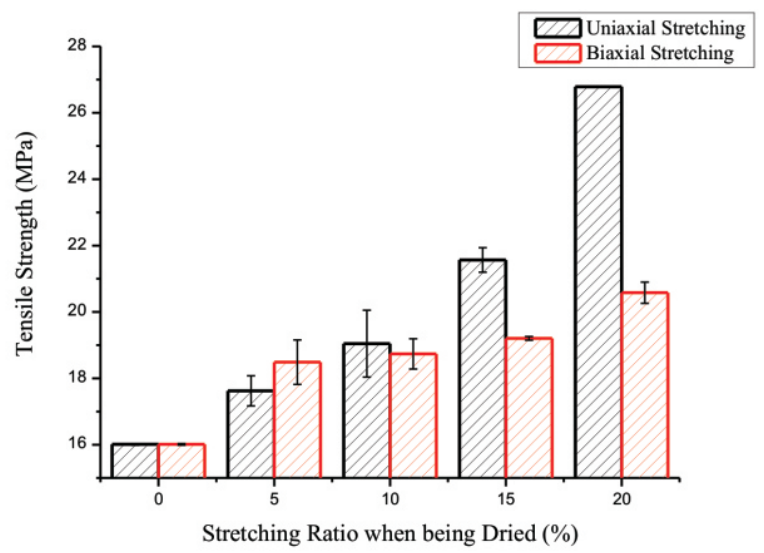

Figure 5. Tensile strength of the samples vs. stretching ratio when being dried at ambient pressure

Figura 5. Rezistenţa la rupere a probelor în funcţie de raportul de întindere la uscare la presiune ambiantă

Figure 5 is the relation between tensile strength of the samples biaxial stretched when being ambient dried and stretching ratio. The tensile strength of the uniaxial stretched samples is higher than that of the biaxial ones, except for that at $5 \%$. That is to say that the uniaxial stretched sample is better than biaxial one in tensile strength. At a small stretching ratio below 5\%, no obvious effect was found of stretching on collagen fiber orientation. When being uniaxial stretched, collagen fibers will orient along the stretching direction, decreasing the fiber braiding angle. For biaxial stretching, however, the collagen fibers have to orient to two perpendicular directions, with the result that no obvious orientation in any direction. Therefore, compared with that of the uniaxial stretched samples, the change in tensile strength of the biaxial stretched one is lower, even lower than that of the uniaxial stretched one. Figure 6 shows the relation between elongation at break and stretching ratios, urmare, gradul de orientare în orice direcţie nu poate fi mai mare decât cel al întinderii uniaxiale. Contribuţia întinderii biaxiale la rezistenţa la rupere este mai mică decât cea a întinderii uniaxiale, având ca rezultat o modificare foarte mică a rezistenţei la rupere a probelor supuse solicitării biaxiale. După întinderea şi uscarea probelor, fibrele de colagen sunt în stare de echilibru parţial. După o nouă solicitare a probelor, va apărea o mică alungire la rupere.

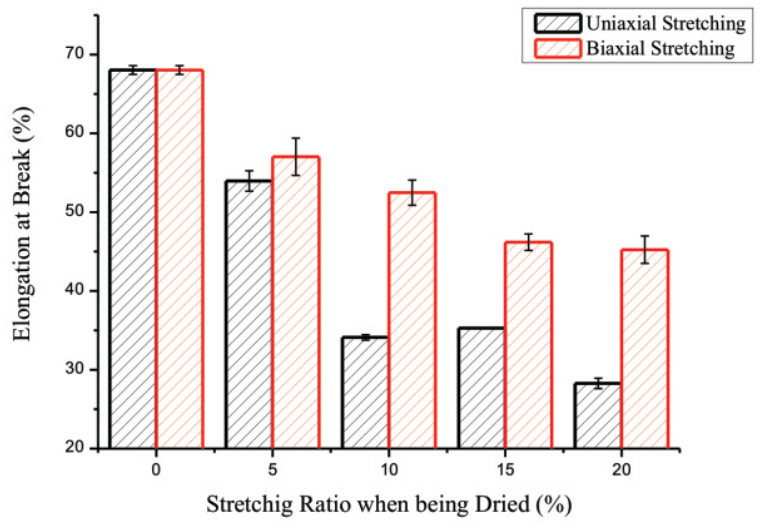

Figure 6. Elongation at break of the samples vs. stretching ratio when being dried at ambient pressure

Figura 6. Alungirea la rupere a probelor în funcţie de raportul de întindere la uscare la presiune ambiantă

Figura 5 prezintă relaţia dintre rezistenţa la rupere a probelor solicitate biaxial în timpul uscării şi raportul de întindere. Rezistenţa la rupere a probelor supuse solicitării uniaxiale este mai mare decât cea a probelor solicitate biaxial, cu excepţia probei cu raport de întindere de $5 \%$. Acest lucru înseamnă că proba solicitată uniaxial are o rezistenţă la rupere mai bună decât cea solicitată biaxial. La un raport de întindere scăzut, sub $5 \%$, nu s-a constatat niciun efect evident al întinderii asupra orientării fibrelor de colagen. La solicitare uniaxială, fibrele de colagen se orientează de-a lungul direcţiei de întindere, ducând la micşorarea unghiului de împletire a fibrelor. La solicitarea biaxială însă, fibrele de colagen trebuie să se orienteze în două direcţii perpendiculare, astfel încât nu există o orientare evidentă în nicio direcţie. Prin urmare, în comparaţie cu probele supuse solicitării uniaxiale, modificările rezistenţei la rupere a probelor solicitate biaxial sunt chiar mai mici decât cele ale probelor solicitate uniaxial. Figura 6 prezintă relaţia dintre alungirea la rupere şi 
both the samples of uniaxial stretched and biaxial stretched at ambient pressure. At the same stretching ratio, the elongation at break of biaxial stretched sample is higher than that of the uniaxial one, and the change is steady. At a higher stretching ratio, a minimum breaking elongation at break appeared for the uniaxial stretched sample. Compared with the uniaxial stretched sample, because of the effect of plane stress, the space between collagen fibers turns great. When being stretched again, more space is available for collagen fibers to move, resulting in a higher elongation at break.

\section{Vacuum Dried Samples}

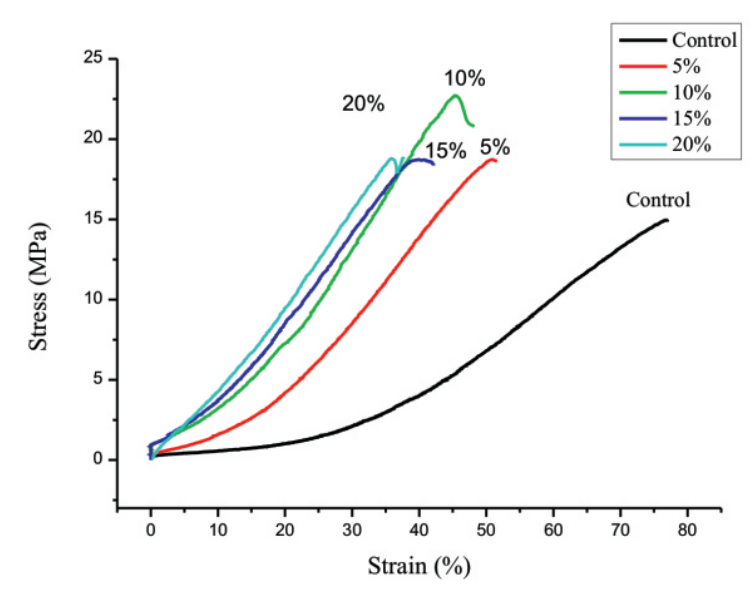

Figure 7. Stress-strain curves of samples uniaxial stretched when being vacuum dried

Figura 7. Curbele de tensiune-deformaţie ale probelor solicitate uniaxial uscate sub vid

From Figure 7 and Figure 8, it is indicated that with the increase of stretching ratio when being vacuum dried, the tensile strength increased first and then, decreased. The highest tensile strength appears at the stretching ratio of $10 \%$. Stretching with vacuum drying drives the stress strain curves moving to the vertical (stress) axis gradually, making the difference to control sample more obvious. So it is suggested that the elastic modulus of the samples is improved by the uniaxial stretching with drying. In general, compared with that of the control sample, the tensile strength of the uniaxial stretched sample while dried is higher, indicating the orientation of collagen fibers along the raportul de întindere, atât pentru probele solicitate uniaxial, cât şi pentru cele solicitate biaxial la presiune ambiantă. La acelaşi raport de întindere, alungirea la rupere a probei supuse solicitării biaxiale este mai mare decât cea a probei solicitate uniaxial, iar schimbarea este constantă. La un raport de întindere mai mare, a apărut o alungire la rupere minimă pentru proba solicitată uniaxial. Comparativ cu proba solicitată uniaxial, din cauza stării plane de tensiune, spaţiul dintre fibrele de colagen se măreşte. Când se întinde proba din nou, fibrele de colagen au mai mult spaţiu de mişcare, având ca rezultat o alungire la rupere mai mare.

Probe uscate sub vid

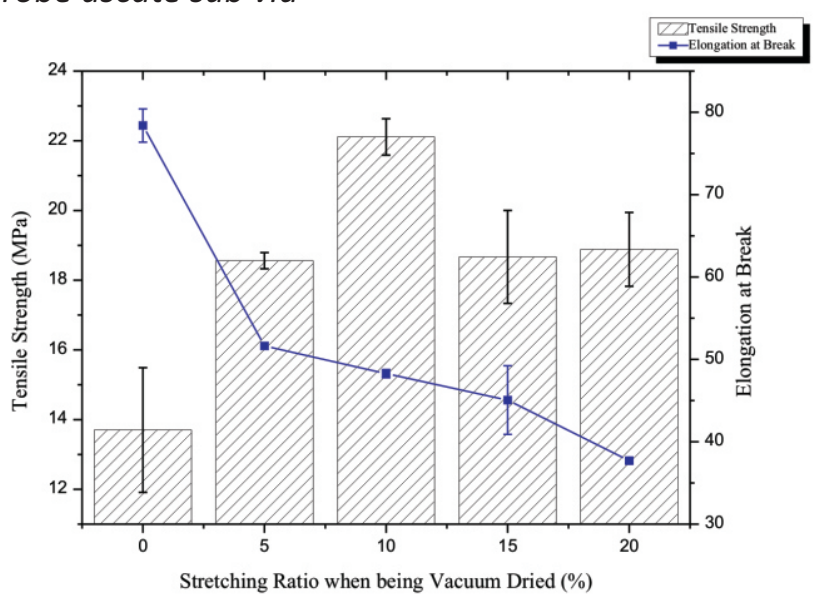

Figure 8. Tensile strength and elongation at break of samples uniaxial stretched when being vacuum dried vs. stretching ratio

Figura 8. Rezistenţa la rupere şi alungirea la rupere ale probelor solicitate uniaxial uscate sub vid în funcţie de raportul de întindere

Din Figurile 7 şi 8 se observă că, odată cu creşterea raportului de întindere în timpul uscării sub vid, rezistenţa la rupere a crescut mai întâi şi apoi a scăzut. Cea mai mare rezistenţă la rupere apare la raportul de întindere de $10 \%$. Solicitarea la întindere în timpul uscării sub vid direcţionează treptat curbele de tensiune şi deformaţie spre axa verticală (tensiune), accentuând mai mult diferenţa faţă de proba martor. Aşadar, se sugerează că modulul de elasticitate al probelor se îmbunătăţeşte prin solicitarea uniaxială în timpul uscării. În general, în comparaţie cu proba martor, rezistenţa la rupere a probei solicitate uniaxiale în timpul uscării este mai mare, indicând orientarea 
stretching direction to improve the strength. The maximum appeared at the stretching ratio of $10 \%$, which indicates that the orientation of collagen fibers reaches the highest value, and further stretching will destroy the internal fibers of networks. With the increase of the stretching ratio at vacuum drying, the elongation at break decreased gradually, probably because the orientation of the collagen fibers increases and the collagen fibers are located in a new position. When being stretched again, the samples are directly in the stretching stage of collagen fibers. The decreased elongation at break appeared.

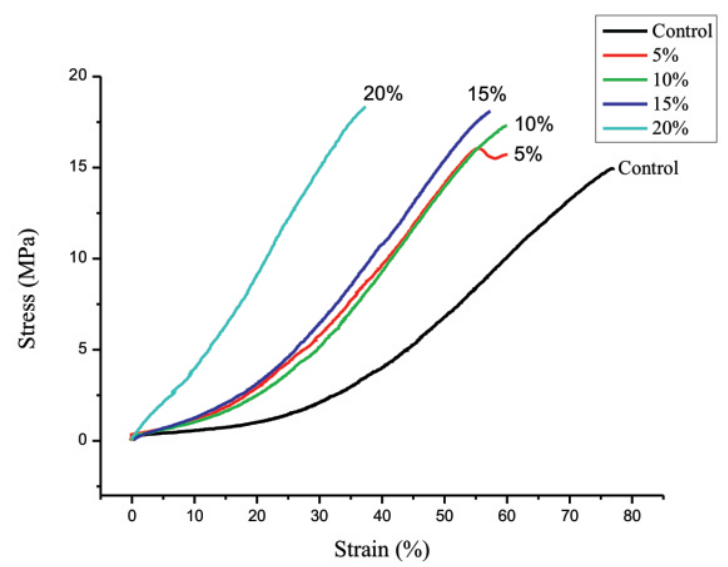

Figure 9. Stress-strain curves of samples biaxial stretched at vacuum drying

Figura 9. Curbele de tensiune-deformaţie ale probelor solicitate biaxial uscate sub vid

The stress-strain curves of samples biaxial stretched when being vacuum dried were shown in Figure 9. Biaxial stretching when being vacuum dried improves the tensile strength and stiffness, but decreases the elongation at break. The trends and shapes of the stress-strain curves of all samples are similar. In terms of tensile strength, compared with the control, it is significantly increased from $13.7 \mathrm{MPa}$ to $16.7 \mathrm{MPa} \sim 18.1 \mathrm{MPa}$ (Figure 10). The influence of stretching ratio on the tensile strength when being vacuum dried is little, located between $16.7 \sim 18.1$ $\mathrm{MPa}$ (Figure 10). When being biaxial stretched, the samples were subjected to a plane stress state, and collagen fibers will turn to orient in two perpendicular directions. The orientation in any one direction is less fibrelor de colagen de-a lungul direcţiei de întindere pentru a îmbunătăţi rezistenţa. Maximul a apărut la raportul de întindere de $10 \%$, ceea ce indică faptul că orientarea fibrelor de colagen atinge cea mai mare valoare, iar o întindere suplimentară va distruge fibrele interne ale reţelelor. Odată cu creşterea raportului de întindere în timpul uscării sub vid, alungirea la rupere scade treptat, probabil pentru că orientarea fibrelor de colagen creşte şi fibrele de colagen se deplasează într-o altă poziţie. La o nouă întindere, probele sunt direct în etapa de întindere a fibrelor de colagen. Apare o alungire la rupere scăzută.

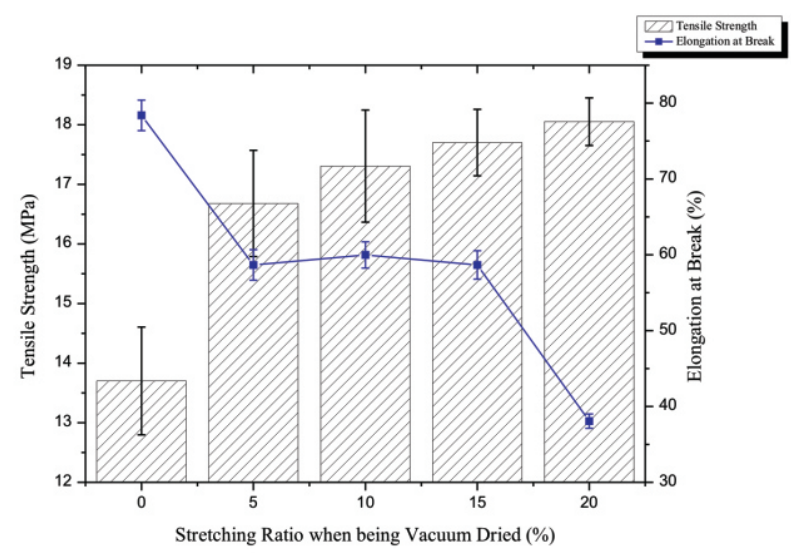

Figure 10. Tensile strength and elongation at break of samples biaxial stretched at vacuum drying vs. stretching ratio

Figura 10. Rezistenţa la rupere şi alungirea la rupere ale probelor solicitate biaxial uscate sub vid în funcţie de raportul de întindere

Curbele de tensiune şi deformaţie ale probelor solicitate biaxial în timpul uscării sub vid sunt prezentate în Figura 9. Solicitarea biaxială în timpul uscării sub vid îmbunătăţeşte rezistenţa la tracţiune şi rigiditatea, dar scade alungirea la rupere. Tendinţele şi formele curbelor de tensiune-deformaţie ale tuturor probelor sunt similare. În ceea ce priveşte rezistenţa la rupere, în comparaţie cu proba martor, aceasta creşte în mod semnificativ de la 13,7 MPa la 16,7 MPa 18,1 MPa (Figura 10). Influenţa raportului de întindere asupra rezistenţei la rupere în timpul uscării sub vid este mică, situată între 16,7 şi 18,1 MPa (Figura 10). La întinderea biaxială, probele au fost supuse unei stări plane de tensiune, iar fibrele de colagen s-au orientat în două direcţii perpendiculare. Orientarea în orice 
than that of the samples being uniaxial stretched. So the strength of the biaxial stretched samples cannot increase very much. With the increase of stretching ratio when being dried, the elongation at break turns to decrease, and no turning was found as that in ambient dried sample. In the vacuum drying, the air pressure is always lower than the ambient pressure. The migration and evaporation of water molecules from the samples will be fastened. However, due to the limitation of air convection, the water vapor cannot be completely transported from the systems, resulting in a higher humidity than the ambient pressure drying. Therefore, the damage of vacuum drying on the collagen structure is relatively small.

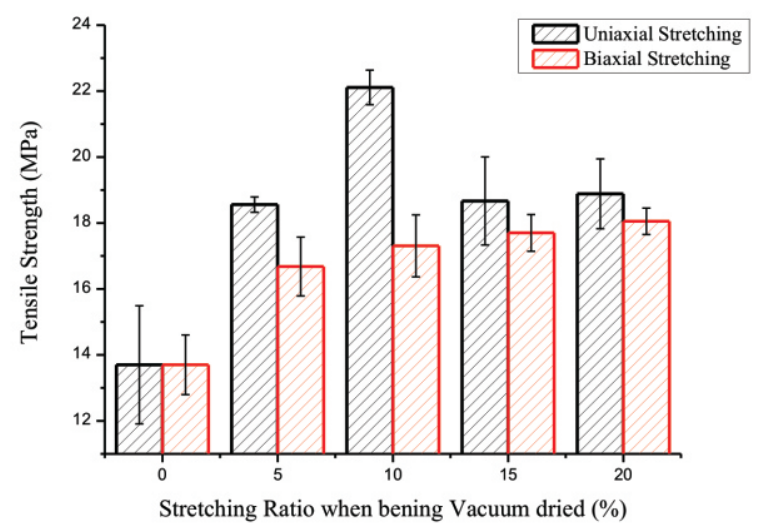

Figure 11. Tensile strength of the samples vs. stretching ratio when being vacuum dried Figura 11. Rezistenţa la rupere a probelor în funcţie de raportul de întindere la uscare sub vid

The relations of tensile strength of both the samples of uniaxial stretched and biaxial stretched when being vacuum dried with the stretching ratio are presented in Figure 11. At the same stretching ratio, the tensile strength of the uniaxial stretched sample is much greater than that of the biaxial stretched one. When being uniaxial stretched, the collagen fibers will orient along the stretching direction to increase the orientation of the samples. Biaxial stretching, however, because of the plane stress state, the orientation to any direction is not high. Figure 12 shows the relationship elongation at break and the stretching ratio of both uniaxial and biaxial stretched samples when being vacuum drying. At a same stretching ratio, the direcţie este mai slabă decât cea a probelor supuse solicitării uniaxiale. Aşadar, rezistenţa probelor supuse solicitării biaxiale nu poate creşte foarte mult. Odată cu creşterea raportului de întindere în timpul uscării, alungirea la rupere scade şi nu s-a constatat nicio modificare în comparaţie cu proba uscată la presiune ambiantă. La uscarea sub vid, presiunea aerului este întotdeauna mai mică decât presiunea ambiantă. Migrarea şi evaporarea moleculelor de apă din probe se vor accelera. Cu toate acestea, datorită limitărilor convecţiei cu aer, vaporii de apă nu pot fi complet transportate din sisteme, având ca rezultat o umiditate mai mare faţă de uscarea la presiune ambiantă. Prin urmare, deteriorarea structurii colagenului cauzată de uscarea sub vid este relativ mică.

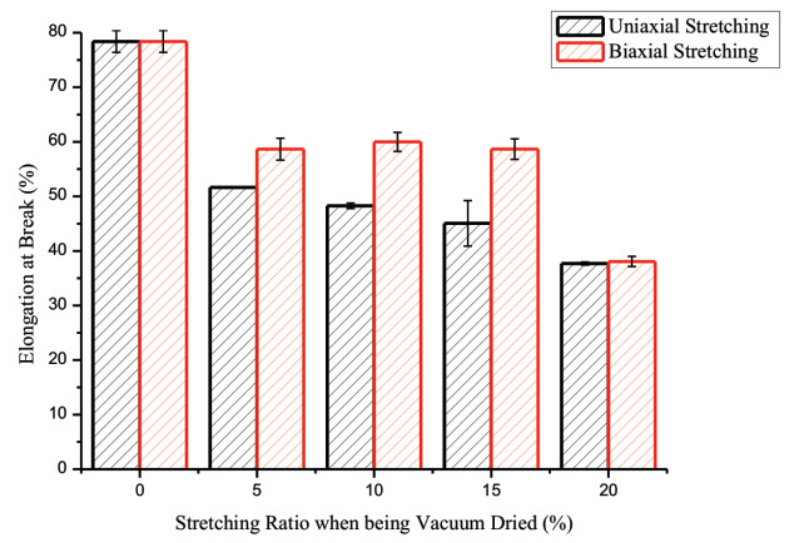

Figure 12. Elongation at break of the samples vs. stretching ratio when being vacuum dried

Figura 12. Alungirea la rupere a probelor în funcţie de raportul de întindere la uscare sub vid

Relaţia rezistenţei la rupere a probelor solicitate uniaxial şi biaxial în timpul uscării sub vid cu raportul de întindere este prezentată în Figura 11. La acelaşi raport de întindere, rezistenţa la rupere a probei supuse solicitării uniaxiale este mult mai mare decât cea a probei solicitate biaxial. La întindere uniaxială, fibrele de colagen se vor orienta de-a lungul direcţiei de întindere pentru a creşte orientarea probelor. La întindere biaxială însă, din cauza stării plane de tensiune, orientarea în orice direcţie nu este mare. Figura 12 arată relaţia dintre alungirea la rupere şi raportul de întindere pentru probele solicitate atât uniaxial, cât şi biaxial în timpul uscării sub vid. La acelaşi raport de întindere, alungirea la rupere a probelor 
elongation at break of biaxial stretched samples is higher than that of uniaxial stretched ones. When being biaxial stretched, because of the two directional stresses, the collagen fibers may loosen to provide some additional spaces for the collagen fibers to move when being stretched again. Therefore, uniaxial stretching may increase the orientation of collagen fibers, while biaxial stretching may loosen the collagen fibers. solicitate biaxial este mai mare decât a celor solicitate uniaxial. La întinderea biaxială, din cauza tensiunii din două direcţii, fibrele de colagen pot slăbi pentru a oferi spaţiu suplimentar pentru deplasare la o nouă întindere. Prin urmare, întinderea uniaxială poate creşte orientarea fibrelor de colagen, în timp ce întinderea biaxială poate slăbi fibrele de colagen.

\section{SEM Images}

\section{Imagini SEM}
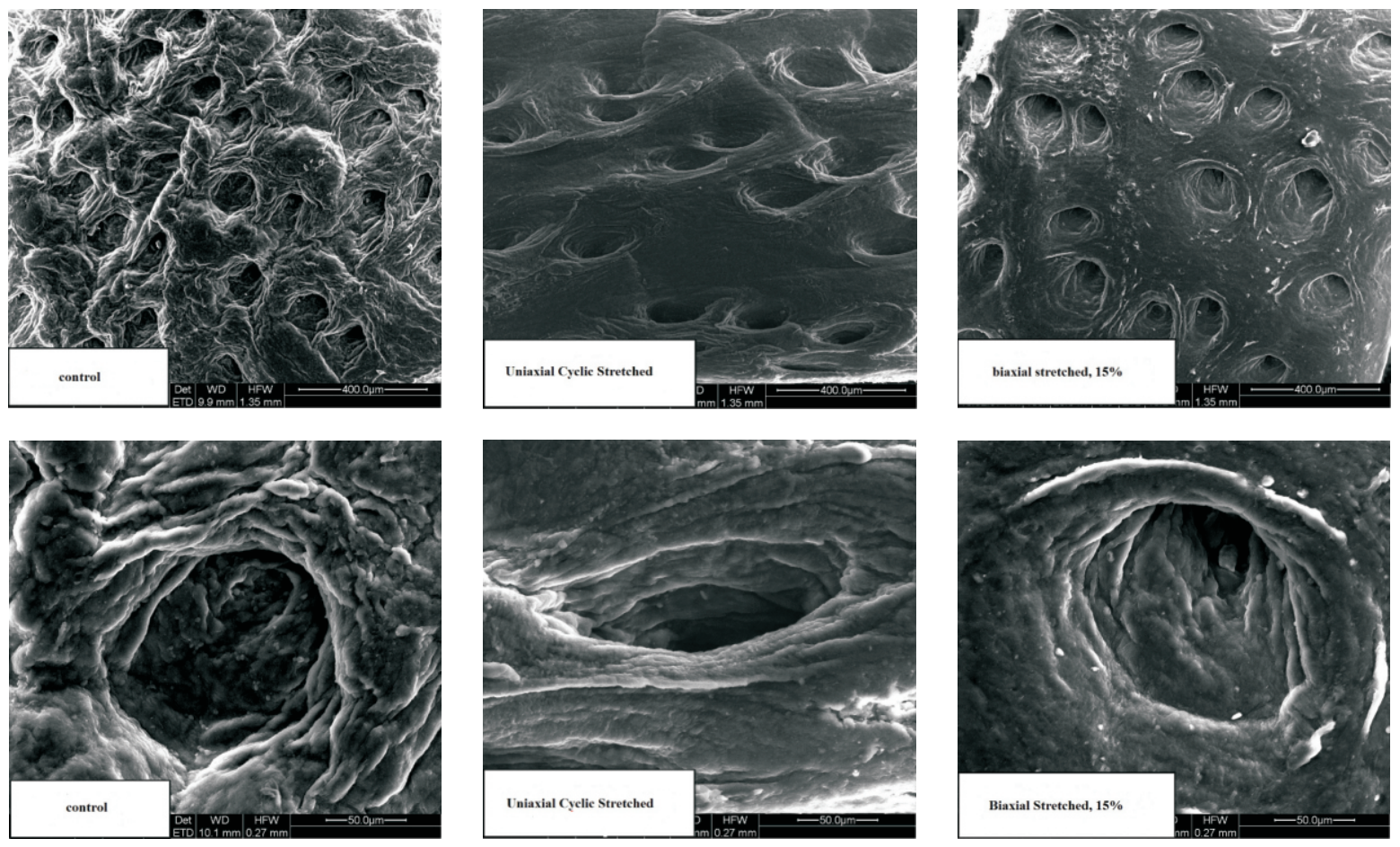

Figure 13. SEM images of the grain surface of the samples stretched at ambient pressure Figura 13. Imagini SEM ale suprafeţei stratului de faţă al probelor solicitate la presiune ambiantă

The scanning electron micrograph of the grain side of the samples stretched when being ambient dried is shown in Figure 13. In Figure 13 it can be found that the grain surface of the control sample without stretching history when being dried is rough. The pore shape is unclear, the smoothness is not good. The hierarchy sense of the pore is strong and the area around the pores is rugged. So the collagen fibers in the control sample are disorderly stacked. The pores in the grain surface of the uniaxial cyclic stretched sample are clear, and turned along the stretching direction to show an oval shape. Around
Microfotografia electronică de baleiaj a stratului de faţă al probelor solicitate la întindere în timpul uscării la presiune ambiantă este prezentată în Figura 13. Din Figura 13 se poate constata că stratul de faţă al probei martor fără întindere în timpul uscării prezintă asperităţi. Forma porilor este neclară, netezimea nu este optimă. Există o ierarhie evidentă a porilor, zona din jurul porilor având un aspect neregulat. Aşadar, fibrele de colagen din proba martor sunt dispuse dezordonat. Porii din stratul de faţă al probei solicitate uniaxial ciclic se pot observa clar şi sunt orientaţi de-a lungul direcţiei de întindere, având o formă ovală. Zona 
the pores are relatively flat, and less hierarchy was found. As to the biaxial stretched sample, the grain surface is very smooth. Besides the big holes, some fine pores may be found. It may be because of the biaxial stretching, which leads to the round pore shape without obvious folding. din jurul porilor este relativ netedă şi se observă o ierarhie mai slabă. În ceea ce priveşte proba solicitată biaxial, stratul de faţă este foarte neted. Pe lângă orificiile mari se pot constata pori fini. Acest lucru se poate datora solicitării biaxiale, ceea ce conduce la forma rotundă a porilor fără pliere evidentă.
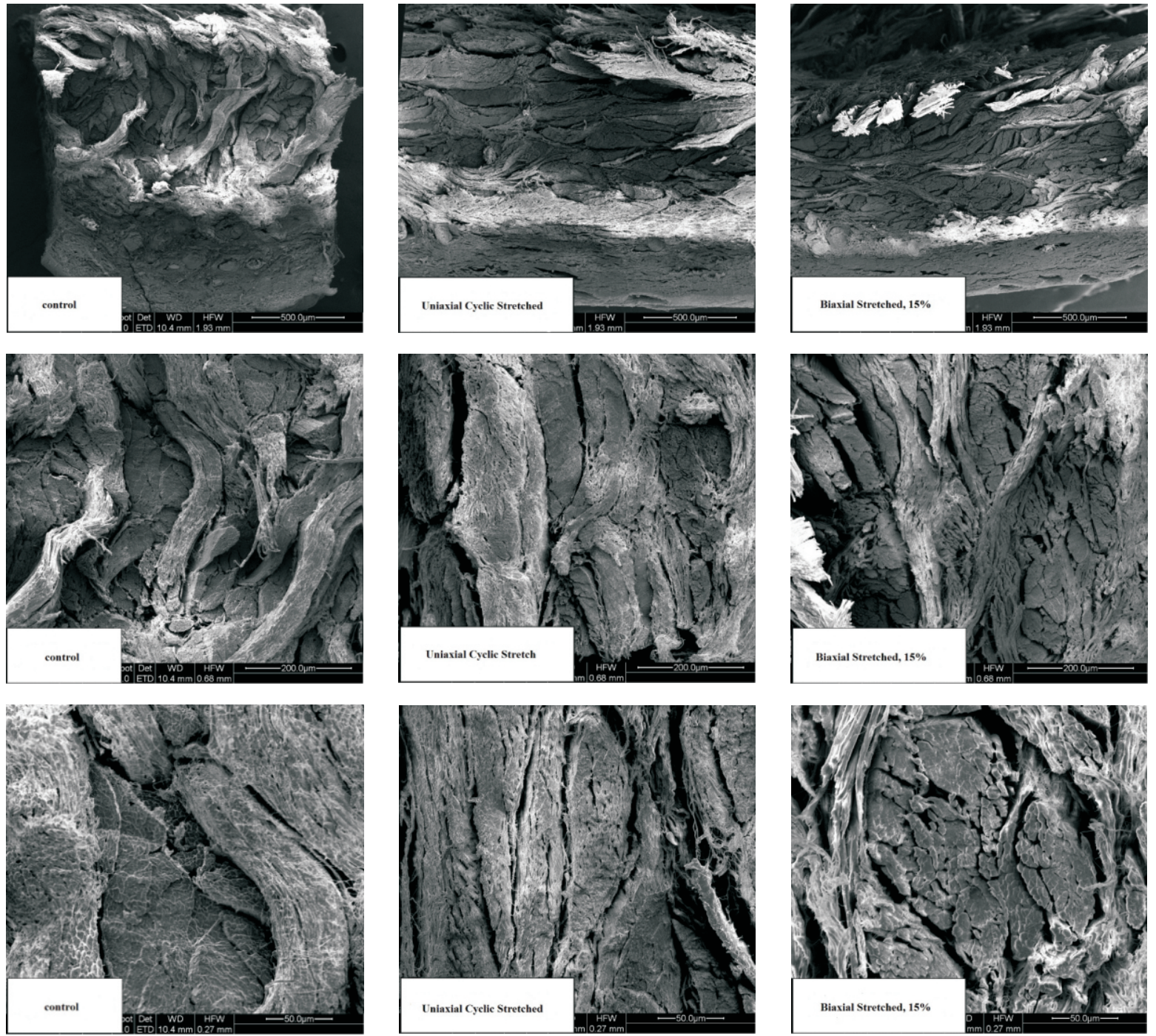

Figure 14. SEM images of the cross section of the samples stretched at ambient pressure Figura 14. Imagini SEM ale secţiunii transversale a probelor solicitate la presiune ambiantă

Figure 14 shows the SEM images of the cross section of the different samples. The three such layers as grain, dermis and suede may be clearly observed. In the control sample, the collagen fibers are randomly stacked and the cross section is rough. As to the uniaxial cyclic stretched one, the collagen fibers orient to the
Figura 14 prezintă imaginile SEM ale secţiunii transversale a diferitelor probe. Cele trei straturi, stratul de faţă, derma şi partea velurată se pot observa în mod clar. La proba martor, fibrele de colagen sunt aranjate aleatoriu, iar secţiunea transversală prezintă asperităţi. În ceea ce priveşte proba solicitată uniaxial 
stretching direction more ordered and closely, with a certain degree of orientation. Compared with that of the control sample, the cross section of the biaxial stretched sample is more orderly. From the one with larger magnification, it is found that the spacing between collagen fibers is larger and the collagen fibers are separated to some degree.

\section{Foundation of Collagen Fibers Structure Model in Leathers}

ciclic, fibrele de colagen se orientează în direcţia de întindere mai ordonat şi mai strâns, cu un anumit grad de orientare. Comparativ cu proba martor, secţiunea transversală a probei solicitate biaxial este mai ordonată. Din imaginea cu mărire mai mare se constată că distanţa dintre fibrele de colagen este mai mare şi fibrele de colagen sunt separate într-o anumită măsură.

\section{Fundaţia modelului de structură a fibrelor de colagen din piele}

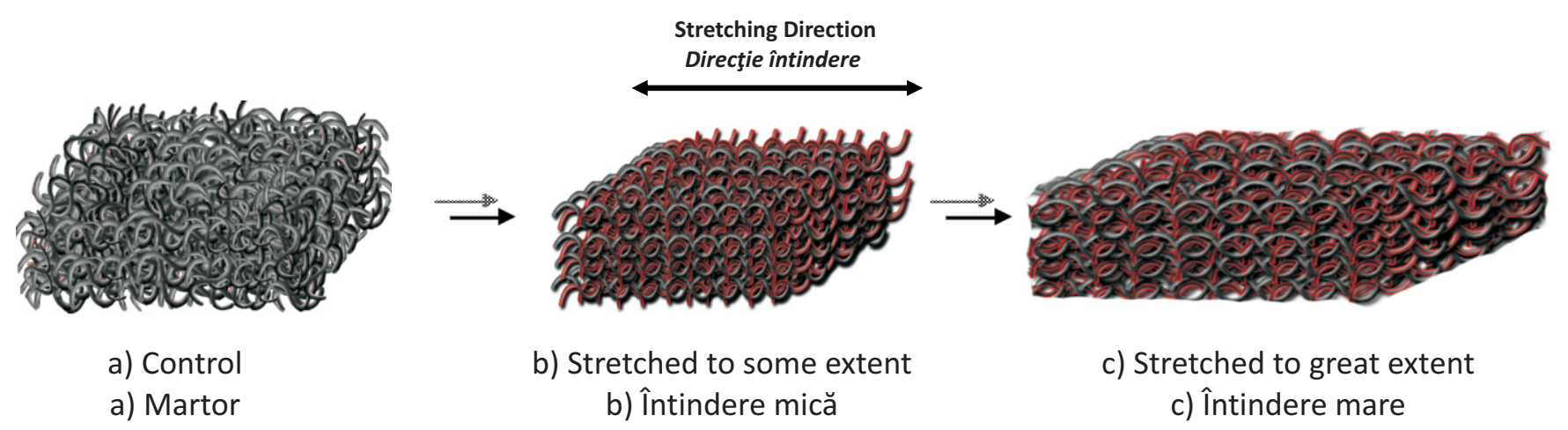

Figure 15. Collagen fibers structure model in leathers

Figura 15. Modelul structurii fibrelor de colagen din piele

According to the results of SEM images and mechanical properties above, the collagen fibers structure model in leathers was proposed as shown in Figure 15. The collagen fibers in the control sample are random distributed with a high braided angle between the collagen fibers. A three-dimensional network structure is formed by the fibers interspersed with each other. When being stretched to a certain degree, the collagen fiber will orient along the stretching direction to a certain degree to decrease the braided angle, while the overall sample turns longer. Stretched to a great degree, the collagen fibers are arranged and stacked more closely, which decreases the braided angle and the overall thickness. Because of the formation of three-dimensional network structure of collagen fibers, both the decrease in braided angle and the increase in orientation degree are limited to a certain extent. Further more stress will lead to the failure of the samples.
Conform imaginilor SEM şi proprietăţilor mecanice de mai sus, s-a propus modelul de structură a fibrelor de colagen din piele prezentat în Figura 15. Fibrele de colagen din proba martor sunt distribuite aleatoriu cu un unghi mare de împletire a fibrelor de colagen. Fibrele intercalate formează o structură de reţea tridimensională. La întinderea până la o anumită limită, fibra de colagen se orientează de-a lungul direcţiei de întindere într-o anumită măsură, unghiul de împletire micşorânduse, în timp ce proba se lungeşte. La o întindere mai mare, fibrele de colagen sunt aranjate mai strâns, ceea ce duce la scăderea unghiului de împletire şi a grosimii totale. Din cauza formării structurii de reţea tridimensională a fibrelor de colagen, atât scăderea unghiului de împletire, cât şi creşterea gradului orientării sunt limitate într-o anumită măsură. Mai mult decât atât, tensiunea va conduce la distrugerea probelor. 


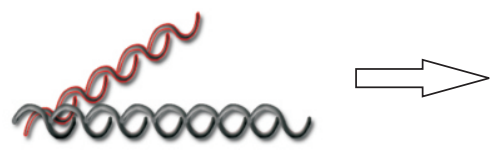

a)

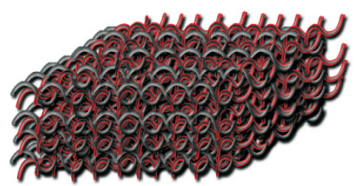

f)

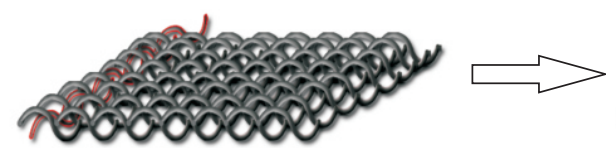

b)

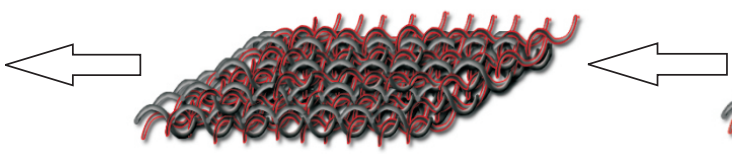

e)
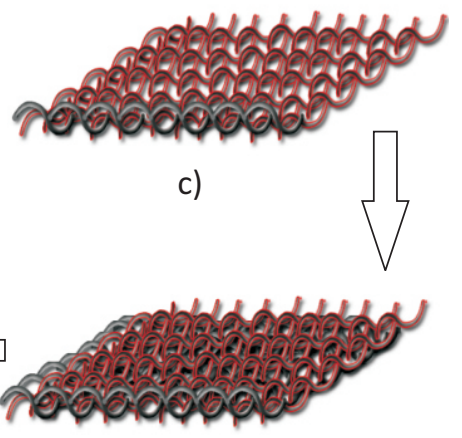

d)

Figure 16. Simplified collagen fiber interwoven structure: (a) Simplified orthogonal basic unit;

(b) Arrangement of collagen fibers along the stretching direction; (c) Arrangement of collagen fibers perpendicular to the stretching direction; (d) orthogonal woven plane; (e) interpenetrating braided plane; (f) stereo structure

Figura 16. Structura întreţesută simplificată a fibrelor de colagen: (a) unitate de bază ortogonală simplificată;

(b) aranjarea fibrelor de colagen de-a lungul direcţiei de întindere; (c) aranjarea fibrelor de colagen perpendicular pe direcţia de întindere; (d) plan întreţesut ortogonal; (e) plan împletitură întrepătrunsă; (f) structură stereo

Figure 16 is a simplified collagen fiber interwoven structure. When being uniaxial stretched, the collagen fibers in the stretching direction are continuously stretched and the fiber braided angle is decreased. With increasing the strain, the collagen fibers perpendicular to the stretching direction will take the action to hinder the decrease in braided angle. The collagen fibers are stacked more closely. Because the collagen fiber network cannot be deformed greatly, fibers perpendicular to the stretching direction will be stretched and separated, which increases the distance between fiber bundles. Therefore, when the samples are uniaxial stretched, the fiber orientation in the stretching direction will increase, and the tensile strength in the stretching direction is increased. When being biaxial stretched, besides the orientation of collagen fibers, the collagen fiber bundles may loosen, resulting in no obvious increase in tensile strength and an obvious increase in elongation at break.

\section{CONCLUSIONS}

Stretching when leathers are being dried increases the tensile strength and stiffness, while decreases the elongation at break of leathers. No matter for ambient pressure drying or vacuum drying, the effect of biaxial stretching on the tensile is not great, but the effect on the elongation at break cannot
Figura 16 prezintă o structură întreţesută simplificată a fibrelor de colagen. La solicitare uniaxială, fibrele de colagen se întind încontinuu în direcţia de întindere şi unghiul de împletire a fibrelor scade. Odată cu creşterea tensiunii, fibrele de colagen perpendiculare pe direcţia de întindere împiedică scăderea unghiului de împletire. Fibrele de colagen sunt aşezate mai strâns. Întrucât reţeaua fibrelor de colagen nu poate fi deformată considerabil, fibrele perpendiculare pe direcţia de întindere se întind şi se separă, ceea ce măreşte distanţa dintre fasciculele de fibre. Prin urmare, atunci când probele sunt solicitate uniaxial, atât orientarea fibrelor, cât şi rezistenţa la rupere în direcţia de întindere cresc. La întindere biaxială, pe lângă orientarea fibrelor de colagen, fasciculele de fibre de colagen pot slăbi, consecinţa fiind nicio creştere evidentă a rezistenţei la rupere şi creşterea evidentă a alungirii la rupere.

\section{CONCLUZII}

Întinderea pielii în timpul uscării creşte rezistenţa la rupere şi rigiditatea acesteia, scăzând în acelaşi timp alungirea la rupere. Indiferent dacă uscarea se face la presiune ambiantă sau sub vid, influenţa solicitării biaxiale asupra rezistenţei la rupere nu este mare, dar influenţa asupra alungirii la rupere nu poate fi neglijată. 
be neglected. Compared with the sample being biaxial stretched, uniaxial stretching leads to increased tensile strength and decreased elongation at break. Stretching improves smoothness of the grain surface of leathers. No stretching when being dried leads to randomly distributed collagen fibers in leathers. Uniaxial stretching increases orientation of the collagen fibers, thereby increasing the tensile strength. Biaxial stretching may loosen the collagen fibers in leather to a certain extent, with the result that the elongation at break is higher than that of the uniaxial stretched one.

\section{Acknowledgements}

The financial supports from the National Natural Science Foundation Commission of China (No. 51373158) and the Sci-Tech. Innovation Talent Foundation of Henan Province (No. 144200510018) are gratefully acknowledged.
Comparativ cu proba solicitată biaxial, solicitarea uniaxială duce la creşterea rezistenţei la rupere şi scăderea alungirii la rupere. Întinderea îmbunătăţeşte netezimea stratului de faţă al pielii. Uscarea pielii fără întindere duce la o dispunere aleatorie a fibrelor de colagen în piele. Întinderea uniaxială creşte orientarea fibrelor de colagen, crescând astfel rezistenţa la rupere. Întinderea biaxială poate slăbi fibrele de colagen din piele într-o anumită măsură, având ca rezultat o alungire la rupere mai mare decât cea obţinută prin întinderea uniaxială.

\section{Mulţumiri}

Autorii mulţumesc pentru sprijin financiar Comisiei Fundaţiei pentru Ştiinţele Naturii din China (nr. 51373158) şi Fundaţiei pentru Talent şi Inovare în Ştiinţă şi Tehnică din provincia Henan (nr. 144200510018).

\section{REFERENCES}

1. Attenburrow, G.E., The Rheology of Leather - A Review, J Soc Leath Tech Ch, 1993, 77, 4, 107-114.

2. Crudu, M., Deselnicu, V., Costache, M., Nicolae, F., Mutlu, M.M., Glumser, G., Bitlisli, B.O., Basaran, B., Adiguzel Zengin, A.C., New Tanning Agents Based on Titanium and Zirconium, Bulletin of Scientific Information of Bioterra University, 2010, 20, 6-13.

3. Crudu, M., Deselnicu, V., Mutlu, M.M., Gulumser, G., Bitlisli, B.O., Basaran, B., Adiguzel Zengin, A.C., New Tanning Agents Based on Titanium and Zirconium, Proceedings of the 3rd International Conference on Advanced Materials and Systems ICAMS, 16-18 September 2010, Bucharest, 27-32, CERTEX Press.

4. Albu, L., Popescu, M., Deselnicu, V., Albu, E., Zainescu, G., Study and Practice on Alternative Eco-friendly Processes for Leather Manufacture, Revista de Pielarie Incaltaminte (Leather and Footwear Journal), 2011, 11, 3, 211-220.

5. Zhang, C.H., Zheng, X.J., Tang, K.Y., Study on the Three-Dimensional Stress-Relaxation Diagram of Cattle Hide Shoe Upper Leathers, Mater Sci Eng A, 2009, 499, 1-2, 167-170.

6. Liu, C.K., Liu, L.S., Latona, N.P., Composite Drying with Simultaneous Vacuum and Toggling, J Am Leather Chem As, 2009, 104, 4, 131-138.

7. Liu, C.K., William, N.M., Nicholas, L. et al., Study on the Physical Properties of Leather, China Leather, 2001, 30, 17, 3033.

8. Du, J., Tang, K.Y., Zhao, K., Influence of Stress State on Dried Leather Yield and Water Vapor Permeability, China Leather, 2014, 43, 1, 23-28. 